Maria Cristina de Queiroz Mendes*, José Marcos de Castro Nunes, Santiago Fraga, Francisco Rodríguez, José Mariano Franco, Pilar Riobó, Suema Branco and Mariângela Menezes

\title{
Morphology, molecular phylogeny and toxinology of Coolia and Prorocentrum strains isolated from the tropical South Western Atlantic Ocean
}

https://doi.org/10.1515/bot-2018-0053

Received 19 May, 2018; accepted 14 February, 2019; online first 13 March, 2019

\begin{abstract}
The morphology, molecular phylogeny and toxinology of two Coolia and one Prorocentrum dinoflagellate strains from Brazil were characterized. They matched with Coolia malayensis and Coolia tropicalis morphotypes, while the Prorocentrum strain fitted well with the morphology of Prorocentrum emarginatum. Complementary identification by molecular analyses was carried out based on LSU and ITS-5.8S rDNA. Phylogenetic analyses of Coolia strains (D1/ D2 region, LSU rDNA), showed that C. malayensis (strain UFBA044) segregated together with sequences of this species from other parts of the world, but diverged earlier in a separate branch to sequences from São Paulo (Brazil) or Caribbean areas. Coolia tropicalis (strain UFBA055) grouped with other sequences of this species, in a subclade with an isolate from Belize, closer to a subgroup including isolates from Thailand, Australia and Hong Kong. Phylogenetic analyses (ITS-5.8S rDNA) of P. emarginatum (strain UFBA033) grouped together with another sequence of this species from China Sea. Diarrhetic shellfish poisoning toxins (OA, DTXs and PTX2) were not detected in
\end{abstract}

\footnotetext{
*Corresponding author: Maria Cristina de Queiroz Mendes, Universidade Federal da Bahia, Instituto de Biologia, Programa de Pós-Graduação em Ecologia e Biomonitoramento (ECOBIO), Av. Barão Jeremoabo, Campus Ondina, Salvador, BA 40170-115, Brasil, e-mail: cristinaqmendes@gmail.com. https://orcid.org/0000-0002-4443-2193 José Marcos de Castro Nunes: Universidade Federal da Bahia, Instituto de Biologia, Laboratório de Algas Marinhas (LAMAR), Av. Barão Jeremoabo, Campus Ondina, Salvador, BA 40170-115, Brasil Santiago Fraga and Francisco Rodríguez: Instituto Español de Oceanografía (IEO), Centro Oceanográfico de Vigo, Subida a Radio Faro, 50, Vigo 36390, Spain

José Mariano Franco and Pilar Riobó: Instituto de Investigaciones Marinas (IIM-CSIC), C/Eduardo Cabello, 6, Vigo 36208, Spain Suema Branco and Mariângela Menezes: Universidade Federal do Rio de Janeiro, Museu Nacional, Departamento de Botânica, Laboratório de Ficologia, Quinta da Boa Vista, São Cristovão, Rio de Janeiro, RJ 20940-040, Brasil
}

P. emarginatum by mass spectrometry analyses. However, hemolytic assays in P. emarginatum and both Coolia strains in this study showed positive results.

Keywords: Coolia malayensis; Coolia tropicalis; hemolytic assay; LC-HRMS; Prorocentrum emarginatum.

\section{Introduction}

Epibenthic dinoflagellate communities harbor potentially harmful species that attracted great interest in the last decades due to their apparent expansion from tropical/ subtropical areas to temperate latitudes (Berdalet et al. 2017). Some of these organisms develop harmful proliferations in coastal areas associated with deleterious effects on marine animals and humans, like cutaneous irritations by skin contact with water or respiratory distress by inhalation of aerosolized toxins (Leaw et al. 2016). These blooms can cause important economic losses, in particular to the industries of aquaculture, recreation, and tourism (Hallegraeff 2010, Migliaccio et al. 2016).

Species of the genera Prorocentrum Ehrenberg and Coolia Meunier are commonly found in epibenthic dinoflagellate communities and co-exist with other potentially toxic benthic dinoflagellates from the genera Ostreopsis J. Schmidt and Gambierdiscus Adachi et Fukuyo (e.g. Leaw et al. 2016).

Toxic effects have been observed in some Coolia species by biological assays on mice, fish, invertebrates or hemolytical assays (Holmes et al. 1995, Leung et al. 2017). In 1995, a possible analog of yessotoxin, named cooliatoxin, was identified in a strain initially identified as Coolia monotis Meunier from Australia (Holmes et al. 1995) and later as Coolia tropicalis Faust (Mohammad-Noor et al. 2013). Some progress has been made since then, but their chemical structure has not been described yet. Recently, five other potential analogs of yessotoxin have been identified in Coolia malayensis Leaw, P.-T. Lim et Usup from Japan (Wakeman et al. 2015). 
Species of Prorocentrum are widely distributed from tropical to temperate/cold waters, comprising both pelagic and benthic species. Currently, among the 80 accepted Prorocentrum taxa, 30 are benthic and, within them, 10 are potentially toxic (Hoppenrath et al. 2014, Nascimento et al. 2017). The morphological differences among benthic Prorocentrum species are sometimes very subtle but some subgroups can be made. One of these subgroups is formed by Prorocentrum emarginatum Fukuyo, Prorocentrum sculptile Faust and Prorocentrum fukuyoi Murray et Nagahama. The morphological features that distinguish these species from each other have not yet been well clarified. On the other hand, species of Prorocentrum have been found to contain genetic diversity among strains and species. Hence, it is necessary to carry out more morphological and molecular studies on isolates from different locations worldwide (Hoppenrath et al. 2014).

Dinoflagellates of the Prorocentrum genus are known producers of okadaic acid (OA) and dinophysistoxins (DTXs; Glibert et al. 2012). They produce lipid-soluble esters called "OA diol esters" as well and water-soluble derivatives of OA and DTX1 diol esters such as DTX4, DTX5a, -b, -c or DTX6 (Torgersen et al. 2008). In addition to those compounds involved in diarrhetic shellfish poisoning (DSP) events, other active and complex metabolites such as prorocentrolides, borbotoxins or spiroprorocentrimine have been also isolated from Prorocentrum spp. (Hoppenrath et al. 2014).

There are few studies about epibenthic dinoflagellates in Brazil. Those available were done in the southeast region of the country and focused mainly on the genus Ostreopsis and its relation with toxic blooms (Nascimento et al. 2008), besides a recent study on a Ostreopsis strain from the northeast region by Mendes et al. (2017). Other studies are available for Prorocentrum lima (Ehrenberg) F. Stein and Coolia malayensis and were carried out with isolates from Rio de Janeiro State (Nascimento et al. 2016) and São Paulo State (Gómez et al. 2016), respectively, close to the Tropic of Capricorn where Prorocentrum emarginatum was also reported although without any morphological or genetic information (Villac and Tenenbaum 2010).
The present study reports the molecular, morphological and toxinological characterization of two isolates of Coolia (C. malayensis and C. tropicalis) and one of Prorocentrum ( $P$. emarginatum) from a tropical area (latitude $13^{\circ} \mathrm{S}$ ) of the South Western Atlantic Ocean.

\section{Materials and methods}

\section{Sampling, strain isolation and culturing}

Two strains (UFBA044 and UFBA055) of Coolia and one (UFBA033) of Prorocentrum were isolated from a mixture of macroalgae collected from a reef plateau located at Bahia in the northeast of Brazil (Table 1, Figure 1). The macroalgal samples were hand-collected and carefully introduced into plastic bags, and vigorously shaken for 2 min to detach the epiphytic cells associated with the macroalgae. Cells of Coolia and Prorocentrum were isolated from the epiphytic suspension using a micropipette under an inverted microscope (trinocular TS100, Nikon, Japan). Isolated cells were kept initially in a 20-well culture plate and then transferred to a 10-ml glass tube with f/2 medium (Guillard and Morton 2004). Monospecific cultures of Coolia and Prorocentrum strains were established and maintained in a temperature-controlled cabinet at $25 \pm 2^{\circ} \mathrm{C}$, with a light:dark cycle of $12 \mathrm{~h}: 12 \mathrm{~h}$ at an irradiance of $\sim 60 \mu \mathrm{mol}$ photon $\mathrm{m}^{-2} \mathrm{~s}^{-1}$ provided by coolwhite fluorescent tubes.

The dinoflagellate strains originated from algal cultures kept in the Laboratório de Algas MarinhasLAMAR/IB/UFBA, Brazil and were incorporated later into the Culture Collection of the Oceanography Center of Vigo (CCVIEO, http://www.vgohab.es/). The strain UFBA033 was lost during the experiment.

\section{Light and epifluorescence microscopy}

Light microscopy (LM) observations were carried out on living or formalin-fixed cells using a Leica DMLA light microscope (Leica Microsystems $\mathrm{GmbH}$, Wetzlar,

Table 1: Sampling data for Prorocentrum emarginatum (strain UFBA033), Coolia malayensis (UFBA044) and C. tropicalis (UFBA055) collected from coastal areas of Bahia State, Brazil.

\begin{tabular}{lllll}
\hline Strain code & Sampling site & Latitude & Longitude & Sampling date \\
\hline UFBA033 & $4^{\mathrm{a}}$ Praia, Morro São Paulo, Cairu, Bahia & $13^{\circ} 23^{\prime} 19.1^{\prime \prime} \mathrm{S}$ & $38^{\circ} 54^{\prime} 11.4^{\prime \prime} \mathrm{W}$ & 2 Dec. 2013 \\
UFBA044 & Pronta do Mutá beach, Barra Grande, Marau, Bahia & $13^{\circ} 52^{\prime} 46^{\prime \prime} \mathrm{S}$ & $38^{\circ} 56^{\prime} 50^{\prime \prime}$ W & 18 March 2014 \\
UFBA055 & $4^{\mathrm{a}}$ Praia, Morro São Paulo, Cairu, Bahia & $13^{\circ} 23^{\prime} 19.1^{\prime \prime} \mathrm{S}$ & $38^{\circ} 54^{\prime} 11.4^{\prime \prime} \mathrm{W}$ & 23 Sept. 2014 \\
\hline
\end{tabular}




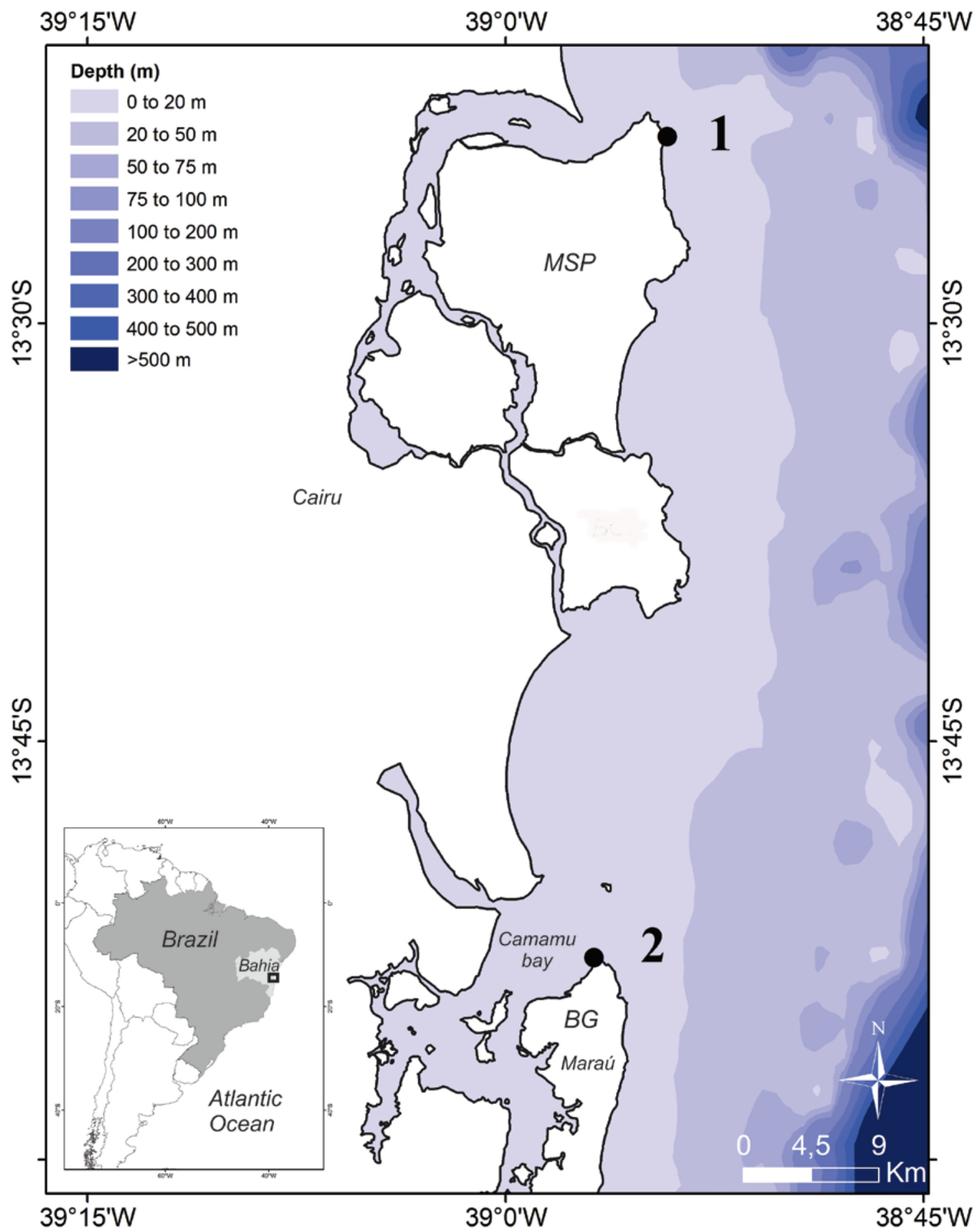

Figure 1: Map showing the bathymetry of the two main sampling sites off the Brazilian Bahia State coast. (1) 4- Praia, Morro de São Paulo (MSP), Cairu; (2) Ponta do Mutá beach - Barra Grande (BG), Marau.

Germany) at the Centro Oceanográfico de Vigo/IEO, Spain. The microscope was equipped with differential interference contrast optics and epifluorescence using calcofluor at $0.15 \mathrm{mg} \mathrm{ml}^{-1}$ to visualize thecal plates (Fritz and Triemer
1985). The microscope had a UV lamp with both UV and blue excitation filters and a digital camera (Axiocam HRc, Carl Zeiss, Jena, Germany) with capture software (Zen image acquisition and analysis, Carl Zeiss, Germany). An 
Olympus microscope (Olympus ${ }^{\circledR}$ trinocular CX31RTS5, Tokyo, Japan) was also available for analyses; the microscope was equipped with a digital camera (QImaging GO-3, QImaging, Sydney, Australia) and the QCapture Pro image-capture program (QImaging), and the analyses were done at the Laboratório de Algas Marinhas-LAMAR/ IB/UFBA, Brazil. Cells were measured using images obtained as described above (LM), at a magnification of $200 \times$ or $400 \times$, both on living and formalin-fixed cells in order to obtain the length (L) and the width (W).

\section{Scanning electron microscopy (SEM)}

Cells were concentrated using a $20-\mu \mathrm{m}$ mesh, washed twice with culture medium and the pellet was maintained in an ethanol/culture medium solution (1:1) for $30 \mathrm{~min}$ for removal of the outermost membrane (Truby 1997). Then the cells were washed with culture medium and fixed with $2 \%$ glutaraldehyde solution for $24 \mathrm{~h}$. Cells were then mounted on a coverslip and dehydrated in an ethanol series (30, 50, 70, 90 and 100\%). Finally, cells were dried with a Leica EM CPD030 Critical Point Dryer (Leica Microsystems, Germany) and mounted on aluminum stubs. Stubs were then coated with a 2-3-nm gold layer (Denton Vaccum LLC Desk IV) and observed using a scanning electron microscope (JEOL JSM 6390LV SEM, JEOL Ltd., Tokyo, Japan) at the Electron Microscopy Platform of the Gonçalo Moniz Institute/FIOCRUZ/Bahia, Brazil.

The Kofoid tabulation nomenclature system was used for Coolia species, as modified by Besada et al. (1982) with plate formula of Po, 4', 6", 6c, ?s, 5"', 2"'”, whereas the terminology in Hoppenrath et al. (2014) was used for Prorocentrum.

\section{Molecular analysis: polymerase chain reaction (PCR), amplification, DNA sequencing and phylogenetic analysis}

The D1/D2 domains of the LSU rRNA gene of strains UFBA044 (Coolia malayensis) and UFBA055 (Coolia tropicalis) were amplified from single cells using the pair of primers D1R/D2C (5'-ACCCGCTGAATTTAAGCATA-3'/5'ACGAACGATTTGCACGTCAG-3'; Lenaers et al. 1989). The amplification reaction mixture $(25 \mu \mathrm{l})$ contained $2.5 \mu \mathrm{l}$ reaction buffer, $2 \mathrm{mM} \mathrm{MgCl}, 0.25 \mathrm{pmol}$ of each primer, $2 \mathrm{mM}$ dNTPs, 0.65 units Taq DNA polymerase (Qiagen, CA, USA; Hilden, Germany) and $2 \mu$ of Milli- $Q$ water containing a single cell. The LSU rRNA gene was amplified in an Eppendorf Mastercycler EP5345 (Eppendorf AG, New York, NY, USA) under the following conditions: initial denaturation at $95^{\circ} \mathrm{C}$ for $1 \mathrm{~min}$, followed by 40 cycles of denaturation at $54^{\circ} \mathrm{C}$ for $1 \mathrm{~min}$, annealing at $72^{\circ} \mathrm{C}$ for $3 \mathrm{~min}$, extension at $72^{\circ} \mathrm{C}$ for $3 \mathrm{~min}$, and a final extension cycle at $72^{\circ} \mathrm{C}$ for $10 \mathrm{~min}$. A 10- $\mu \mathrm{l}$ aliquot of each PCR reaction was checked by agarose gel electrophoresis $(1 \%$ TAE, $50 \mathrm{~V}$ ) and SYBR Safe DNA gel staining (Invitrogen, Carlsbad, CA, USA). The PCR products were purified with ExoSAP-IT (USB Corp., Cleveland, OH, USA), sequenced using Big Dye Terminator v3.1 Reaction Cycle Sequencing kit (Applied Biosystems, Foster City, CA, USA) and migrated in an AB 3130 Sequencer (Applied Biosystems, Foster City, CA, USA) at the C.A.C.T.I. sequencing facilities (Centro de Apoyo Científico Tecnolóxico á Investigación, Universidade de Vigo, Spain).

For the ITS1-5.8S-ITS2, DNA was extracted from a pellet from $5 \mathrm{ml}$ of culture in exponential phase from the Prorocentrum emarginatum strain UFBA033 harvested by centrifugation, followed by extraction using a NucleoSpin ${ }^{\circledR}$ Plant II extraction kit according to the manufacturer's protocol (Macherey-Nagel GmbH \& Co. KG, Düren, Germany). The ITS1/ITS2 (including 5.8S gene) rDNA fragment was amplified using primers ITSA (5'-GTAACAAGGTHTCCGTAGGT-3') and ITSB (5'-AKATGCTTAARTTCAGCRGG-3') (Sato et al. 2011). Genomic DNA was amplified in a PCR solution containing 1X Colorless GoTaq ${ }^{\circledR}$ Flexi buffer (Promega, Madison, WI, USA), $1.25 \mathrm{mM} \mathrm{MgCl}_{2}$ (Promega), $0.8 \mathrm{pmol}$ of each primer, $0.16 \mathrm{mM}$ dNTP (Thermo Scientific Inc., Waltham, MA, USA), 1 U GoTaq ${ }^{\circledR}$ DNA polymerase (Promega), $0.2 \mu \mathrm{g}$ of Bovine Serum Albumin (New England Biolabs Inc., Ipswich, MA, USA), 15 ng of DNA and Milli-Q water to complete $25 \mu \mathrm{l}$ of solution.

The PCR conditions were as follows: initial denaturation at $94^{\circ} \mathrm{C}$ for $5 \mathrm{~min}$, followed by 40 cycles of denaturation at $94^{\circ} \mathrm{C}$ for $1 \mathrm{~min}$, annealing at $45^{\circ} \mathrm{C}$ for $1 \mathrm{~min}$, an extension at $72^{\circ} \mathrm{C}$ for $1 \mathrm{~min}$ and a final extension at $72^{\circ} \mathrm{C}$ for $5 \mathrm{~min}$. The PCR products were purified and sequenced by Macrogen (Seoul, Korea), in both directions, using the PCR primers. The LSU rDNA and ITS and sequences obtained in this study were deposited in GenBank (see Tables 2 and 3, respectively).

\section{Phylogenetic analysis}

LSU and ITS rDNA sequences were aligned using Bioedit v. 7.2.5 (Hall 1999). The alignment of LSU rDNA sequences of Brazilian strains of Coolia (UFBA044 and UFBA055, with 309 and 304 base pairs (bp), respectively), included 37 Coolia sequences retrieved from GenBank (Table2) and two Ostreopsis sequences, O. siamensis J. Schmidt (FN256430) and O. cf. ovata Fukuyo (JX065588) as outgroups. 
Table 2: List of Coolia strains used for phylogenetic reconstruction and their GenBank accession numbers.

\begin{tabular}{|c|c|c|c|c|c|}
\hline Strain code & Species & GenBank & Strain code & Species & GenBank \\
\hline VG0786 & C. canariensis & AM902737 & Com.5 & C. monotis & KJ781414 \\
\hline VG0787 & C. canariensis & AM902738 & CCMP2582 & C. monotis & KP172277 \\
\hline CcanLSU1 & C. cf. canariensis & KP145681 & Cp1208-1 & C. palmyrensis & KP172270 \\
\hline VG0775 & C. cf. canariensis & AM902739 & Copa11506-2 & C. palmyrensis & KU058189 \\
\hline SKLMP-W075 & C. cf. canariensis & KX589159 & SKLMP-S017 & C. palmyrensis & KX589146 \\
\hline SKLMP-W100 & C. cf. canariensis & KX589160 & SKLMP-S018 & C. palmyrensis & KX589147 \\
\hline UFBA044 & C. malayensis & KY912159 & SKLMP-W085 & C. palmyrensis & KX589148 \\
\hline CAWD39 & C. malayensis & U02258 & Cs1303-1- & C. santacroce & KР172271 \\
\hline CM0607-1 & C. malayensis & KP172278 & $\operatorname{Cos} 1503 \mathrm{GA}$ & C. santacroce & KT288059 \\
\hline CCMP1345 & C. malayensis & AM902743 & $\operatorname{Cos} 1503-2$ & C. santacroce & KT288058 \\
\hline Cm1303-1 & C. malayensis & KP172269 & $\operatorname{Cos} 1503-1$ & C. santacroce & KT288057 \\
\hline K-0972 & C. malayensis & JX896690 & UFBA055 & C. tropicalis & KY912160 \\
\hline L31 & C. malayensis & KM259618 & SKLMP-S002 & C. tropicalis & KX589144 \\
\hline NQAIF35 & C. malayensis & HQ897274 & SKLMP S003 & C. tropicalis & KX589145 \\
\hline 25 & C. malayensis & KU746834 & $\mathrm{CT} 1 \mathrm{C} 1$ & C. tropicalis & AB908159 \\
\hline 52 & C. malayensis & KU746832 & K-1156 & C. tropicalis & JX896691 \\
\hline 74 & C. malayensis & KU746833 & CCMP1744 & C. tropicalis & AM902741 \\
\hline Dn24EHU & C. monotis & HQ414218 & NQAIF90 & Coolia sp. ${ }^{a}$ & HQ897276 \\
\hline CCMP304 & C. monotis & KP172276 & RCC1518 & Coolia sp. & KT860564 \\
\hline RIK24 & C. monotis & AM902749 & & & \\
\hline
\end{tabular}

In bold, strains used in this study.

${ }^{a}$ Currently identified as C. tropicalis (Leung et al. 2017).

Table 3: List of Prorocentrum strains used for phylogenetic reconstruction and their GenBank accession numbers.

\begin{tabular}{|c|c|c|c|c|c|}
\hline Strain code & Species & GenBank & Strain code & Species & GenBank \\
\hline CCMP1724 & P. arabianum ${ }^{\mathrm{a}}$ & EU927555 & TI0124 & P. lima & KY010236 \\
\hline VG0776 & P. arenarium & EU244470 & TI0175c & P. lima & KY010235 \\
\hline CCMP1260 & P. balticum & EU927547 & TI0177c & P. lima & KY010237 \\
\hline CCMP1787 & P. balticum & EU927548 & $\mathrm{PA}$ & P. lima & EU927487 \\
\hline BPHV-1 & P. belizeanumb & JQ638934 & $4 \mathrm{~V}$ & P. lima & EU244474 \\
\hline UFBA064 & P. caipirignum & KY039500 & CCMP686 & P. lima & EU927505 \\
\hline CCMP1768 & P. compressum & EU927558 & USMA-4 & P. lima & AB189759 \\
\hline DS4E11 & P. concavum & KY010228 & TI0139 & P. maculosum & KY010240 \\
\hline DS4F8 & P. concavum & KY010229 & T10102 & P. maculosum & KY010239 \\
\hline \multirow[t]{3}{*}{ RCC848 } & P. dentatum & FJ823581 & CCMP687 & P. mexicanum & EU927554 \\
\hline & P. donghaiense & HQ833324 & CCMP1591 & P. micans & EU927527 \\
\hline & P. donghaiense & AY465115 & CCAP1136/15 & P. micans & EU927531 \\
\hline Dn208EHU & P. elegans & KF835602 & CCAP1136/17 & P. micans & EU927532 \\
\hline UFBA033 & P. emarginatum & KY912158 & CCAP1136/18 & P. micans & EU927533 \\
\hline $\mathrm{X} 2 \mathrm{P} 3$ & P. emarginatum & KY010245 & CCMP2812 & P. minimum & EU927544 \\
\hline NG2 & P. fukuyoi & KY010249 & CCAP1136/16 & P. minimum & EU927545 \\
\hline CCMP2804 & P. hoffmannianum & KF885224 & RCC291 & P. minimum & EU927546 \\
\hline CCMP683 & P. hoffmannianum & KF885225 & TI097 & P. panamense & KY010244 \\
\hline CCMP2794 & P. koreanum & KP711354 & PXHV-1 & P. rhathymum & JQ638938 \\
\hline TI0153 & P. koreanum & KY010231 & PR1VS & P. rostratum & EU244471 \\
\hline LMBEV9 & P. koreanum & KP711351 & & P. texanum & JQ390505 \\
\hline TI063 & P. koreanum & KY010230 & PT2V & P. triestinum & EU244468 \\
\hline VG0880 & P. levis & FJ489615 & VG0672 & P. triestinum & EU244469 \\
\hline USSP-S18 & P. lima & AB189752 & CCMP700 & P. triestinum & EU927549 \\
\hline BM-U2-D5 & P. lima & AB189755 & & & \\
\hline
\end{tabular}

In bold, strain used in this study.

Currently reported as: ${ }^{a} P$. concavum (Gómez 2005); ${ }^{b} P$. hoffmannianum species complex (Herrera-Sepúlveda et al. 2015); ${ }^{c} P$. caipirignum (Nascimento et al. 2017). 
Net average genetic distances $\left(\mathrm{dA}=\mathrm{d}_{\mathrm{XY}}-\left(\mathrm{d}_{\mathrm{X}}+\mathrm{d}_{\mathrm{Y}}\right) / 2\right)$, where $\mathrm{d}_{\mathrm{XY}}$ is the average distance between groups $\mathrm{X}$ and $\mathrm{Y}$, and $d_{X}$ and $d_{Y}$ are the mean within-group distances (Nei 1987), were calculated between Coolia clades for the original alignment using MEGA 7 software.

The best nucleotide substitution model was selected using the model selection tool in MEGA 7 software (Kumar et al. 2016), based on maximum likelihood (ML) as the statistical method. This procedure evaluates the fit of 24 different nucleotide substitution models to the data and those with the lowest Bayesian information criterion (BIC) scores are considered to best describe the substitution pattern. The TN93 model with invariant sites $(I=0.26)$ was selected and the robustness of the ML tree topology was evaluated using bootstrap with 1000 replications (Tamura and Nei 1993).

Regarding ITS rDNA of the Brazilian Prorocentrum UFBA033 strain, the alignment included 48 Prorocentrum sequences retrieved from Genbank and two Alexandrium sequences, A. minutum Halim (KX599348) and A. tamiyavanichi Balech (AF145224) as outgroups (Table 3). The final alignment included $491 \mathrm{bp}$. Model selection of ML was performed as above and a Kimura 2-parameter model (Kimura $1980)$, with gamma distribution $(\gamma=0.65)$, was chosen in MEGA 7. The phylogenetic relationships were also determined using Bayesian phylogenetic inference and, in this case, the substitution models were obtained by sampling across the entire general time reversible (GTR) model space following the procedure described in Mr. Bayes v3.2 manual.

Bayesian trees were performed with Mr. Bayes v3.2 and the program parameters were statefreqpr $=$ dirichlet $(1,1,1,1)$, nst $=$ mixed, rates $=$ gamma (Huelsenbeck and Ronquist 2001). The phylogenetic analyses involved two parallel analyses, each with four chains. Starting trees for each chain were selected randomly using the default values for the Mr. Bayes program. The corresponding number of unique site patterns for LSU and SSU alignments were 259 and 466, respectively. The number of generations used in these analyses was 2,000,000. Posterior probabilities were calculated from every 100th tree sampled after log-likelihood stabilization ("burn-in" phase). All final split frequencies were $<0.03$.

\section{Toxin analysis}

Toxic activity was evaluated by hemolytic assay for strains UFBA033, UFBA044 and UFBA055. UFBA033 strain was also analyzed by LC-HRMS to confirm the identity of toxins involved in its toxic activity. Cultures in exponential phase for all three strains were processed for analyses: $480 \mathrm{ml}$ of Prorocentrum emarginatum (UFBA033) containing
$7.9 \times 10^{5}$ cells ml ${ }^{-1}, 430 \mathrm{ml}$ of Coolia malayensis containing $1.1 \times 10^{6}$ cells ml ${ }^{-1}$ and $370 \mathrm{ml}$ of Coolia tropicalis containing $1.1 \times 10^{6}$ cells ml-1. Firstly, an aliquot of $1.5 \mathrm{ml}$ from the culture was fixed with Lugol and cells were counted using a Sedgewick-Rafter counting slide in LM using a Zeiss Invertoscop D (Carl Zeiss Ag, Germany). The remaining culture volumes were filtered through 47-mm glass microfiber filters (MFV4, C de-Parmer Instrument, Filter-Lab, USA) and maintained at $-20^{\circ} \mathrm{C}$ with $\mathrm{MeOH}$ until further analyses. Then, the cells in the filters were re-suspended in $\mathrm{MeOH}$ and disrupted by sonication using a 4710 probe of the Ultrasonic Homogenizer (Cole-Palmer, Chicago, IL, USA). Next, cells were decanted by centrifugation at $5411 \mathrm{~g}$ for $10 \mathrm{~min}$ at $10^{\circ} \mathrm{C}$ using a Sigma $3-16 \mathrm{KL}$ centrifuge. The supernatants were removed, and pellets were extracted again with $\mathrm{MeOH}$, followed by homogenization in vortex and centrifugation following the same procedure as previously mentioned. Both supernatants were combined and the total volume $(3 \mathrm{ml})$ was stored at $-20^{\circ} \mathrm{C}$ until its analysis by LC-HRMS and hemolytic assays. The toxic activity of dinoflagellate extracts UFBA033, UFBA044 and UFBA055 was checked by delayed hemolysis of sheep erythrocytes following Riobó et al. (2008).

\section{Liquid chromatography-high resolution mass spectrometry (LC-HRMS)}

Only UFBA033 extract was analyzed by LC-HRMS. Mass spectrometry analyses were performed using a Thermo Scientific Dionex LC coupled to an Exactive mass spectrometer, equipped with an Orbitrap mass analyzer. The instrument was mass calibrated for positive and negative modes, and the capillary and tube lens voltages were also optimized, using the automated script within the Exactive acquisition software in both cases. High resolution mass spectrometry experiments were carried out in positive and negative modes, with and without complete ion fragmentation (AIF) (HCD $35 \mathrm{eV}$ ). The mass range for both of them, full mass spectrometry and AIF mode, ranged from 100 to $1500 \mathrm{~m} / z$ with a resolving power at 70,000.

The following conditions were used: a GeminiNX C18 column, $3.5 \mu \mathrm{m} 50 \times 2.10 \mathrm{~mm}$ (Phenomenex) was kept at $40^{\circ} \mathrm{C}$ and eluted at $0.4 \mathrm{ml} \mathrm{min}^{-1}$ with $0.05 \%$ ammonia (eluent A) and 95:5 (acetonitrile:0.05\% ammonia) (eluent B). The following gradient elution was used: $25 \%$ $\mathrm{B}$ at $\mathrm{t}=0,25 \% \mathrm{~B}$ at $\mathrm{t}=1.5,95 \% \mathrm{~B}$ at $\mathrm{t}=7.5,95 \% \mathrm{~B}$ at $\mathrm{t}=9.5$, $25 \% \mathrm{~B}$ at $\mathrm{t}=12.5$, and hold for $1.5 \mathrm{~min}$. For toxin identification, an analytical standard mix solution in methanol was used; the mix contained $20 \mathrm{ng} \mathrm{ml}^{-1}$ of each of the following toxins: OA, DTX2, DTX1 and pectenotoxin-2 (PTX2). 


\section{Results}

\section{Morphology}

Cells of Coolia malayensis (strain UBFA044) were spherical in ventral (Figure 2A) and dorso-ventral (DV) view (Figure $2 \mathrm{~B})$, varying from 26.7 to $38.8 \mu \mathrm{m}(33.6 \pm 3.4$; SD, $\mathrm{n}=27)$ in length and from 25.6 to $37.5 \mu \mathrm{m}(32.1 \pm$ SD 3.3) in DV width. In ventral view, the cells showed an equatorial cingulum, plate $\mathrm{c} 1$ between plates $1^{\prime}$ and $2^{\prime \prime \prime}$ and plate $\mathrm{c} 6$ between plates 6" and 5"' (Figure 2D). Thecal plates were covered by rounded pores distributed throughout the cell (Figure 2H, I). The Po was relatively straight and measured $6.0 \mu \mathrm{m}$ in length (Figure 2I). The first apical plate (1') was oblong, while the third ( $\left.3^{\prime}\right)$ and the fourth ( $\left.4^{\prime}\right)$ apical plates were pentagonal and hexagonal, respectively (Figure 2G). The third postcingular plate ( $\left.3^{\prime \prime \prime}\right)$ was larger than the fourth plate (4"'; Figure 2F).

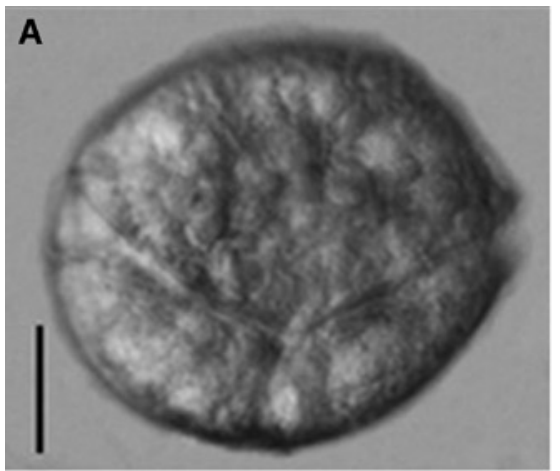

D
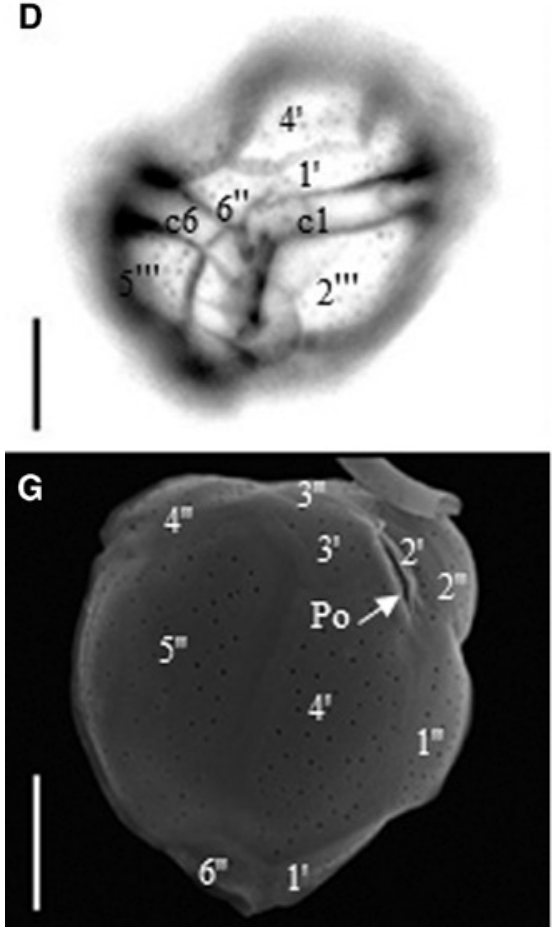

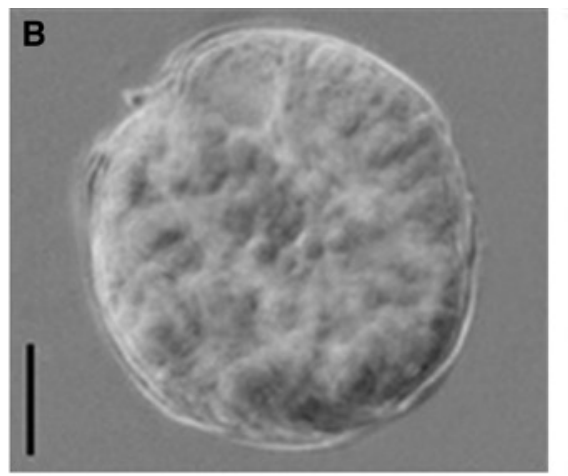

E
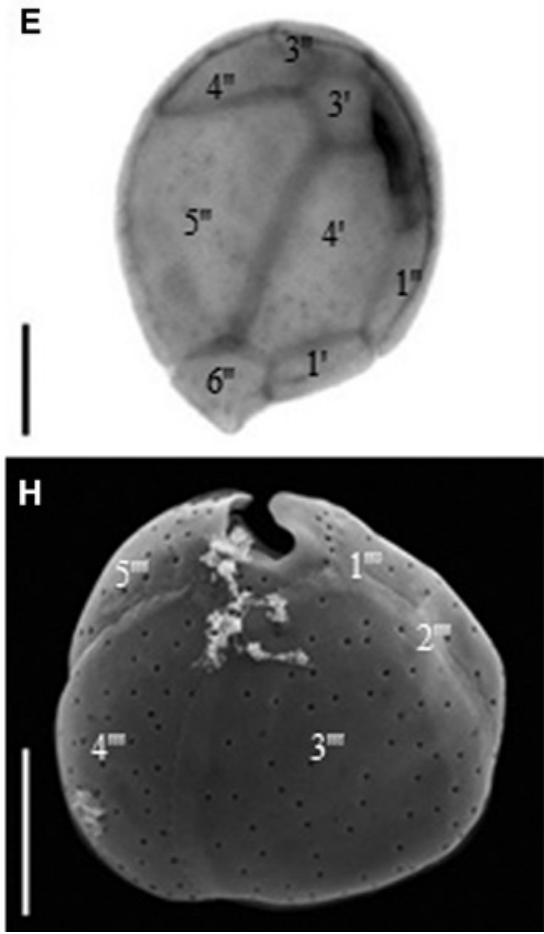

C

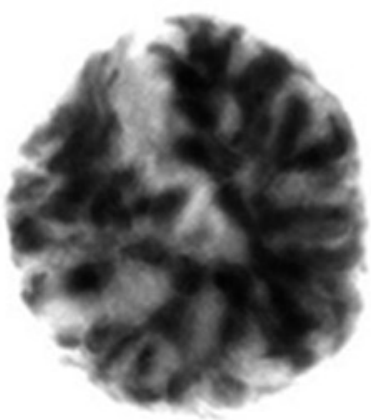

F
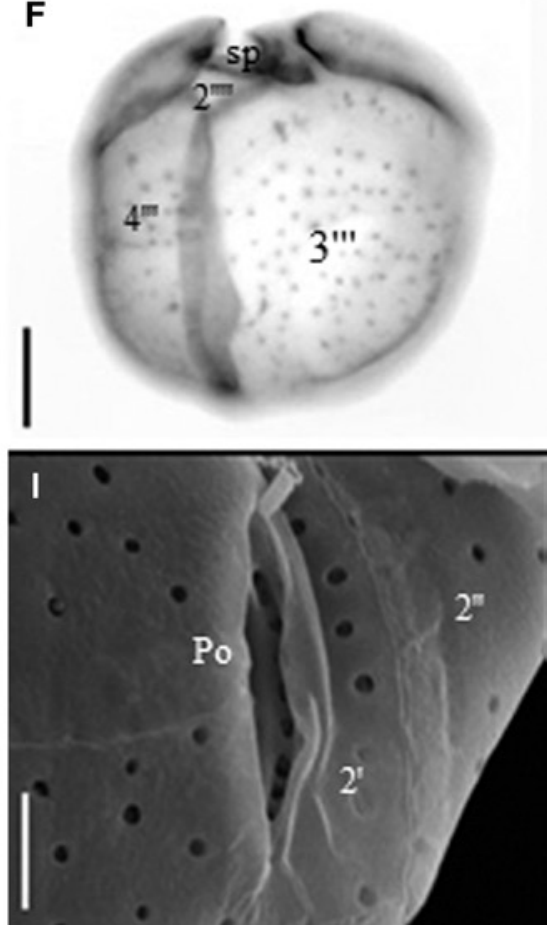

Figure 2: Coolia malayensis (UFBA044): LM and SEM images.

(A) Cell in ventral view in LM. (B) Cell in dorso-ventral view in LM. (C) Cell showing details of the chloroplasts in epifluorescence. (D-F) Cells stained with calcofluor in epifluorescence. (D) Cell in ventral view showing the cingular plates $c 1$ and $c 6$, the apical plates $1^{\prime}$ and $4^{\prime}$, the precingular plate $6^{\prime \prime}$ and the postcingular plates $2^{\prime \prime \prime}$ and $5^{\prime \prime \prime}$. (E) Cell in apical view showing the apical plates $1^{\prime}, 3^{\prime}$ and $4^{\prime}$, and the precingular plates $1^{\prime \prime}, 3^{\prime \prime}-6^{\prime \prime}$. (F) Cell in antapical view showing the sulcal posterior plate (sp), the antapical plate ( $\left.2^{\prime \prime \prime \prime}\right)$ and the postcingular plates $3^{\prime \prime \prime}$ and $4^{\prime \prime \prime}$. (G-I) Cells in SEM images. (G) Cell in apical view showing the apical pore plate (Po), the apical plates $1^{\prime}-4^{\prime}$ and the precingular plates $1^{\prime \prime}-6 "$. (H) Cell in dorsal view showing the postcingular plates $1^{\prime \prime \prime}-5^{\prime \prime \prime}$. (I) Details of the apical pore plate (Po) with the apical plate $2^{\prime}$ and the precingular plate $2^{\prime \prime}$. Scale bars $=10 \mu \mathrm{m}$ (Figure A-H); $2 \mu \mathrm{m}$ (Figure I). 
In Coolia tropicalis (strain UFBA055), the cells were spherical (Figure 3A, C, D, F, G). Cell size varied from 32.5 to $46.3 \mu \mathrm{m}(37.7 \pm \mathrm{SD} 4 ; \mathrm{n}=20)$ in length and from 28.8 to $43.8 \mu \mathrm{m}(35.9 \pm \mathrm{SD} 3.5 ; \mathrm{n}=20)$ in DV width. In ventral view, the cells showed an equatorial cingulum with the plate c6 between plates 6" and 5"' (Figure 3F). Thecal plates were covered by rounded pores distributed throughout the cell (Figure 3G) and in the cingulum (Figure 3F, arrows), and were rosette-shaped when observed from the inner side of the theca (Figure $3 \mathrm{H}, \mathrm{I}$, arrows). The Po was slightly curved and measured 4.9 $\mu \mathrm{m}$ in length (Figure 3I). The fourth apical plate (4') was enlarged towards the ventral margin and it was the largest of the epitheca (Figure 3B). Plates $4^{\prime}$ and 5" showed nearly similar size in apical view (Figure 3B, H), with plate $4^{\prime}$ sometimes slightly larger than $5^{\prime \prime}$ in lateral ventral view (Figure 3G). The sixth precingular plate (6") was approximately three times wider than long
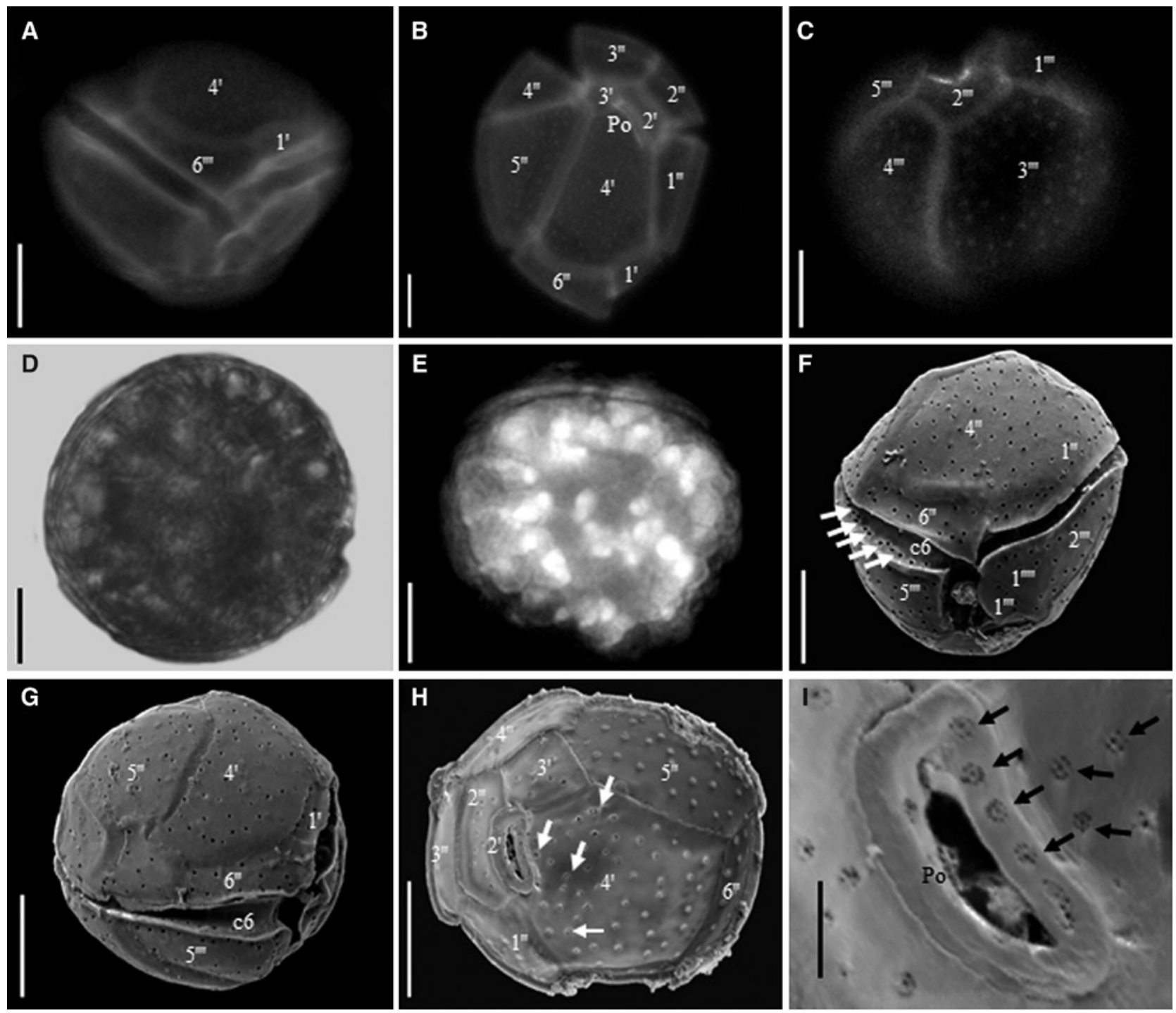

Figure 3: Coolia tropicalis (UFBA055): LM and SEM images.

(A-C) Cells stained with calcofluor in epifluorescence. (A) Cell in ventral view showing the apical plates $1^{\prime}$ and $4^{\prime}$, and the postcingular plate $6^{\prime \prime \prime}$. (B) Cell in apical view showing the apical pore plate (Po), the apical plates $1^{\prime}-4^{\prime}$ and the precingular plates $1^{\prime \prime}-6$. . (C) Cell in dorsal view showing the postcingular plates $1^{\prime \prime \prime}-5^{\prime \prime \prime}$. (D) Cell in dorso-ventral view in LM. (E) Cell showing details of the chloroplasts in epifluorescence. (F-I) Cell in SEM images. (F) Cell in apical view showing the cingular plate $c 6$, the precingular plates 1", 4" and 6", the postcingular plates $1^{\prime \prime \prime}, 2^{\prime \prime \prime}$ and $5^{\prime \prime \prime}$, and the antapical plate $\left(1^{\prime \prime \prime}\right)$; arrows indicate row of rounded pores in the cingulum. (G) Cell in ventral view showing the cingular plate $c 6$, the apical plates $1^{\prime}$ and $4^{\prime}$, the precingular plates $5^{\prime \prime}$ and $6^{\prime \prime}$, and the postcingular plate $5^{\prime \prime \prime}$. (H) Internal face of cell in apical view showing the apical plates $2^{\prime}-4^{\prime}$ and the precingular plates $1^{\prime \prime}-6^{\prime \prime}$; arrows indicate pores with rosette-shaped poroids. (I) Details of the apical pore plate (Po); arrows indicate details of the pores with rosette-shaped poroids. Scale bars =10 $\mu \mathrm{m}$ (Figure A-H); $2 \mu \mathrm{m}$ (Figure I). 
(Figure 3A, B, F). The third (3"') and the fourth ( $\left.4^{\prime \prime \prime}\right)$ plates were almost equal in size (Figure 3C).

Cells of Prorocentrum emarginatum (strain UFBA033) were broadly oval and asymmetric in valve view (Figure 4A). Cell dimensions varied from 31.7 to $41.7 \mu \mathrm{m}$ $(37.9 \pm$ SD 2.8; $\mathrm{n}=23)$ in length and from 28.3 to $36.7 \mu \mathrm{m}$ (32.5 \pm SD 1.9; $\mathrm{n}=23$ ) in DV width. Cell binary division was observed inside a hyaline mucilaginous division cyst with three (Figure 4B), five or two cells (Figure 4C). The thecal surface was foveate with radial rows or double rows of pores perpendicular to the periphery. The central area of the valve was without pores (Figure 5A, B). The intercalary band appears finely striated with close rows of minute marginal pores on both sides (Figure 5C, D). The anterior end of the right valve was deeply indented (Figure 5D). The periflagellar area was narrowly V-shaped and nine platelets were observed, with plate 6 in two parts, $6 \mathrm{a}$ and $6 \mathrm{~b}$ (Figure 5E, F). There was a wing-shaped spine bordering platelet 1 on the dorsal side (Figure 5E).

\section{Molecular analysis: LSU and ITS-5.8S rDNA regions}

The LSU rDNA sequences confirmed the previous morphological identification of UFBA044 as Coolia malayensis and of UFBA055 as Coolia tropicalis, while ITS-5.8S rDNA region also confirmed UFBA033 as Prorocentrum emarginatum. Data on sequences and GenBank accession numbers are shown in Tables 2 and 3. Coolia malayensis (UFBA044), the strain from Bahia, Brazil, segregated with other sequences of this species with strong bootstrap support (100\%) and posterior probability values of 1 (Figure 6) but, in our phylogeny, diverged earlier than other $C$. malayensis sequences. Coolia malayensis from São Paulo, Brazil (KU746832, KU746833) clustered with sequences from the Virgin Islands (KP172269), North Carolina (KP172278) and New Zealand (KM259618), and formed a subgroup with low bootstrap support $(<50 \%)$ and posterior probability $(<0.5)$. A third subgroup included strains from other parts of the world, including Caribbean areas, with low bootstrap support $(<50 \%)$ and low posterior probability $(<0.5)$, as well as strain K0972 isolated near the type locality of $C$. malayensis (Figure 6). Net genetic distance within C. malayensis sequences (excluding UFBA044) was 0.004 ( $p$-distance) and 0.005 between these and the $C$. malayensis UFBA044 strain. The latter value was much lower than net genetic distances calculated between Coolia clades/species (0.107-0.415).

Coolia tropicalis (UFBA055), from Bahia, Brazil, grouped with other sequences of this species (Figure 6) with a strong bootstrap support (100\%) and posterior probability values (1). In this analysis, two subclades were observed, one with a sequence from Malaysia (JX896691) and a second with slightly divergent subgroups with high support (91\%) and low posterior probability values $(<0.5)$. The clade of $C$. tropicalis also showed a certain degree of intraspecific divergence (0.023, $p$-distance). The Brazilian C. tropicalis strain grouped with a sequence from Belize (AM902741) and was closer to the subclade formed by sequences from Thailand (AB908159) and Australia (HQ897276), both as Coolia sp., than the subclade formed by Hong Kong (KX589144 and KX589145) and
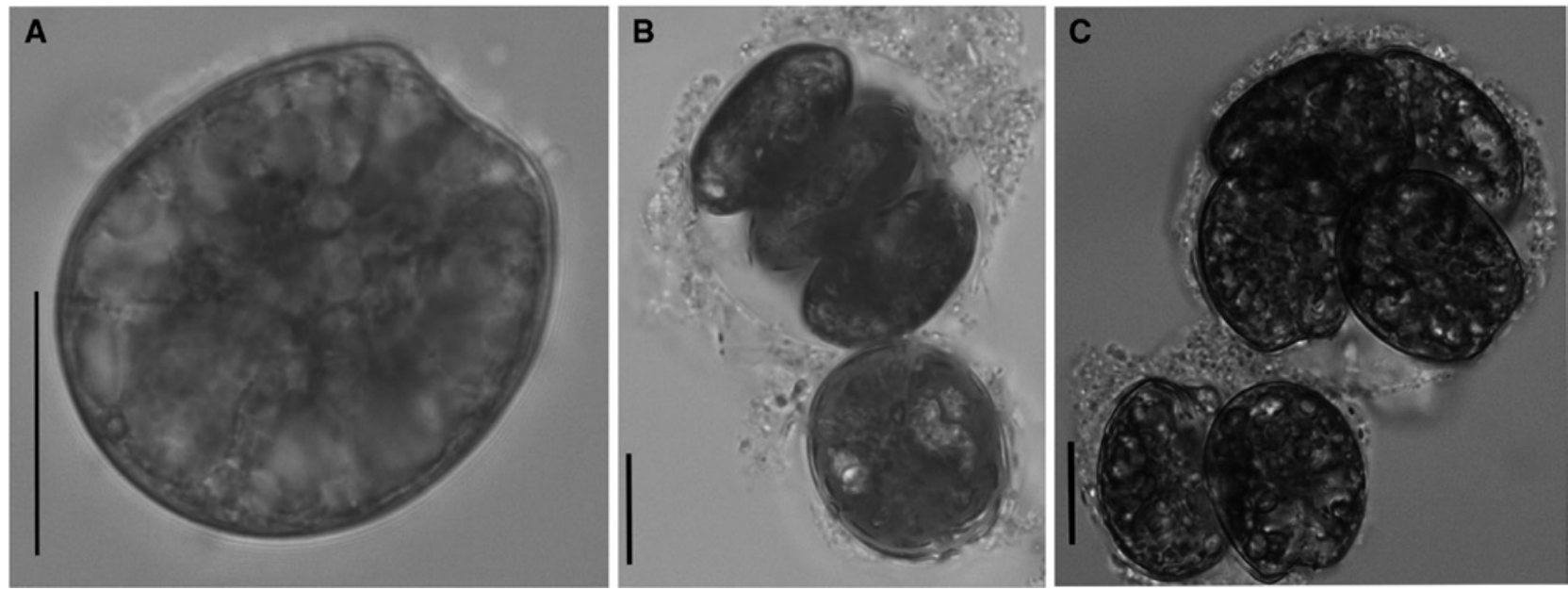

Figure 4: Prorocentrum emarginatum strain in LM.

(A) Solitary vegetative cell. (B) Division cyst with three cells in hyaline mucilage. (C) Two division cysts, one with five and the other with two cells in hyaline mucilage. Scale bar $=20 \mu \mathrm{m}$. 

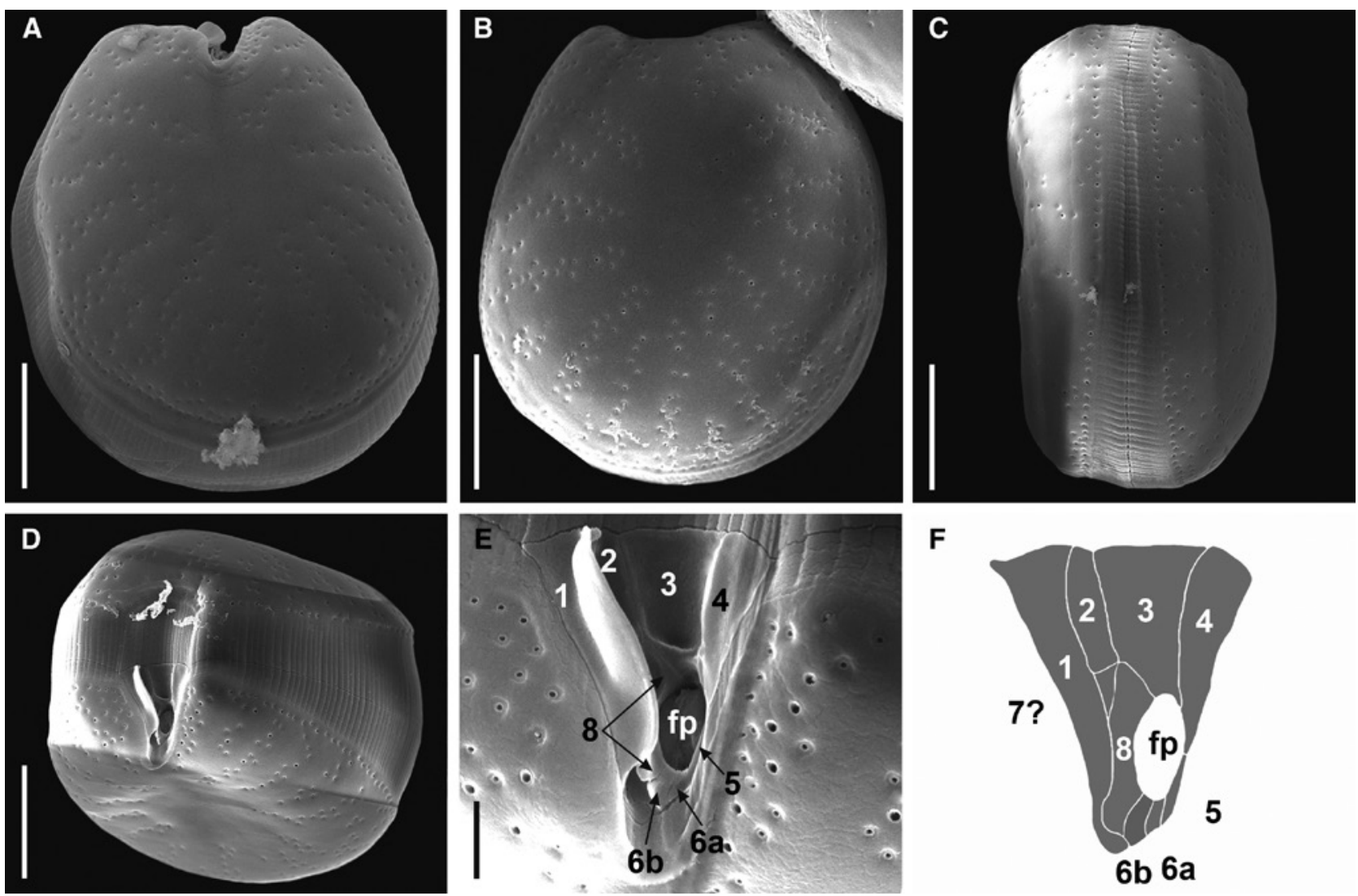

Figure 5: Prorocentrum emarginatum strain in SEM.

(A) Right valve. (B) Left valve. (C) Cell in lateral view showing the intercalary band transversely striated. (D) Cell in an anterior end view showing the striated intercalary band. (E) Periflagellar area showing the 1-6a, $6 \mathrm{~b}$ and 8 platelet arrangement around the flagellar pore (fp). (F) Schematic representation of the 8-platelet arrangement around the flagellar pore (fp). Scale bars $=10 \mu \mathrm{m}$ (Figure A-D); $2 \mu \mathrm{m}$ (Figure E).

Malaysia (JX896691) sequences that emerged as a separate subclade.

The phylogenetic results based on ITS-1/5.8S/ITS-2 regions were in agreement with other phylogenetic studies of Prorocentrum which showed asymmetrical and symmetrical species of the genus split into two separate main clades (Figure 7; Boopathi et al. 2015). One clade included asymmetrical species with variable valve morphology, which were represented by $P$. balticum (Lohmann) Loeblich III, P. compressum (Bailey) Abé ex Dodge, $P$. dentatum F. Stein, $P$. donghaiense D. Lu, P. elegans Faust, $P$. emarginatum, P. fukuyoi, P. koreanum Han, Cho et Wang, P. mexicanum Osorio-Tafall, P. micans Ehrenberg, P. minimum (Pavillard) Schiller, P. panamense Grzebyk, Sako et Berland, P. rhathymum Loeblich III, Sherley et Schmidt, P. rostratum F. Stein, $P$. texanum Henrichs, Steidinger, Scott et Campbell and P. triestinum Schiller. These species were clustered together with high bootstrap support (91\%) and low posterior probability $(<0.5)$ and, exceptionally, with symmetrical species (P. concavum Fukuyo) with moderate bootstrap support
$(68 \%)$ and low posterior probability $(<0.5)$. The other main clade included symmetrical species ( $P$. arenarium Faust, $P$. leve Faust, Kibler, Vandersea, Tester et Litaker, $P$. lima, P. caipirignum Fraga, Menezes et Nascimento and the $P$. hoffmannianum/belizeanum complex) supported with high bootstrap (98\%) and high posterior probability values (0.99).

The Prorocentrum emarginatum strain (UFBA033) was grouped with the asymmetrical species clade and formed a subclade with another P. emarginatum sequence (KY010245) from the South China Sea, with a strong bootstrap support (100\%) and a strong posterior probability (1), together with Prorocentrum fukuyoi with moderate bootstrap (78\%) and high posterior probability.

\section{Toxin analysis: hemolytic assay and LC-HRMS}

Results from hemolytic assays revealed that all tested strains of Prorocentrum emarginatum, Coolia malayensis and Coolia 


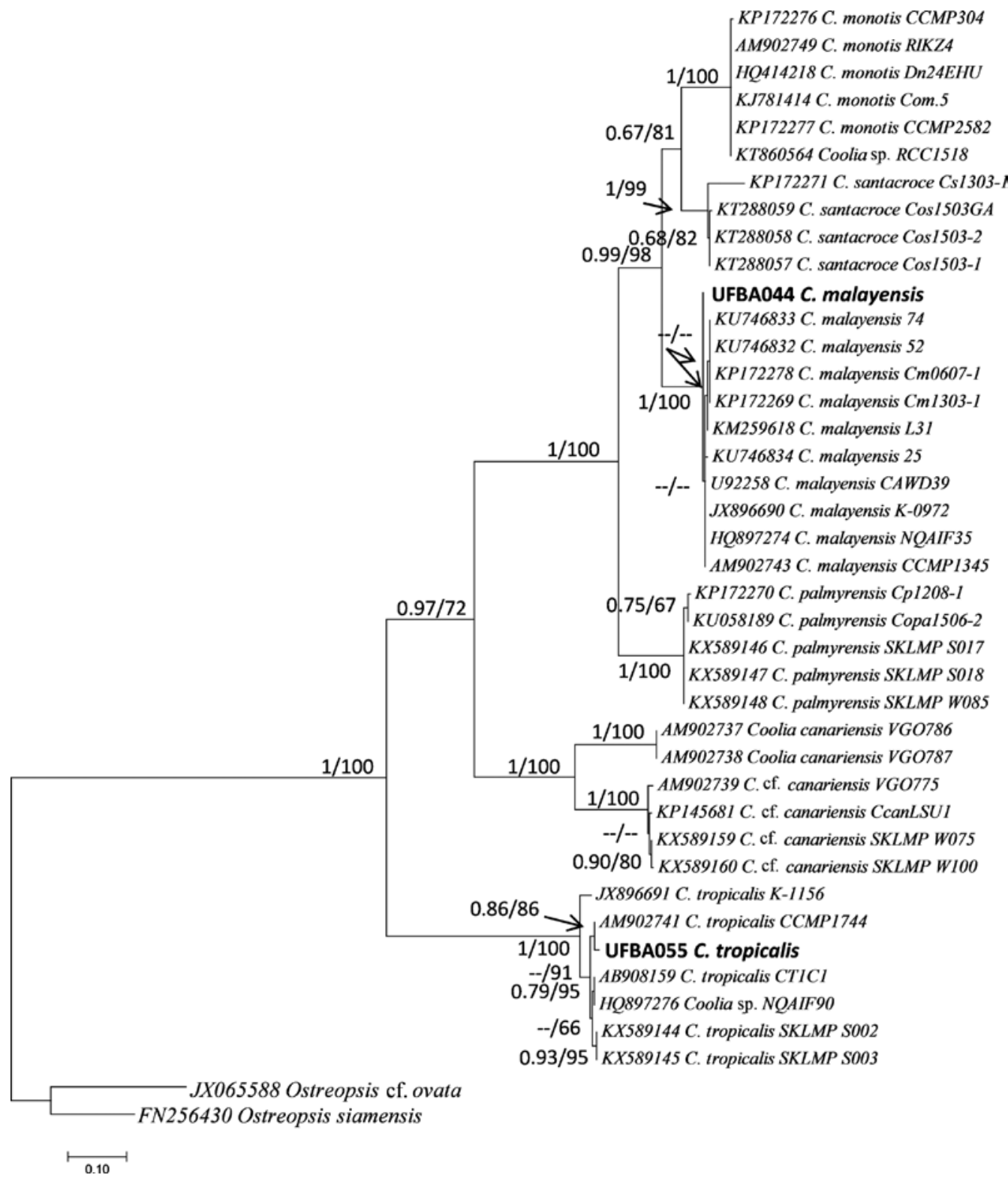

Figure 6: LSU phylogeny (D1/D2 regions) showing the relationship between Coolia malayensis (UFBA044) and C. tropicalis (UFBA055) (in bold) and other Coolia species.

Supports at internal nodes are bootstrap values obtained by the maximum likelihood method and Bayesian inference. Hyphens indicate low bootstrap values $(<50 \%)$ and posterior probability $<0.5$.

tropicalis caused the lysis of erythrocytes. Lipophilic toxins (OA, DTX2, DTX1 and PTX2) were not detected by LC-HRMS analyses in the P. emarginatum strain UFBA033.

\section{Discussion}

The morphospecies Coolia malayensis, Coolia tropicalis and Prorocentrum emarginatum were identified in the studied area. The taxonomic characterization of these morphospecies was confirmed by genetic sequencing.
The distinction between Coolia species based on morphology has been a matter of debate (Laza-Martinez et al. 2011, Mohammad-Noor et al. 2013, Leaw et al. 2016). However, it has been pointed out that the sizes and shapes of the fourth apical (4') and sixth precingular (6") plates are consistent with molecular data and these have been used to circumscribe the species of the genus, in particular, the width: length ratio of the 6" plate (Leaw et al. 2016). Phenotypic plasticity in dinoflagellates has been frequently reported due to environmental factors and to the occurrence of cryptic species. The delimitation of 
- KX599348 Alexandrium minutum CCMP 1888

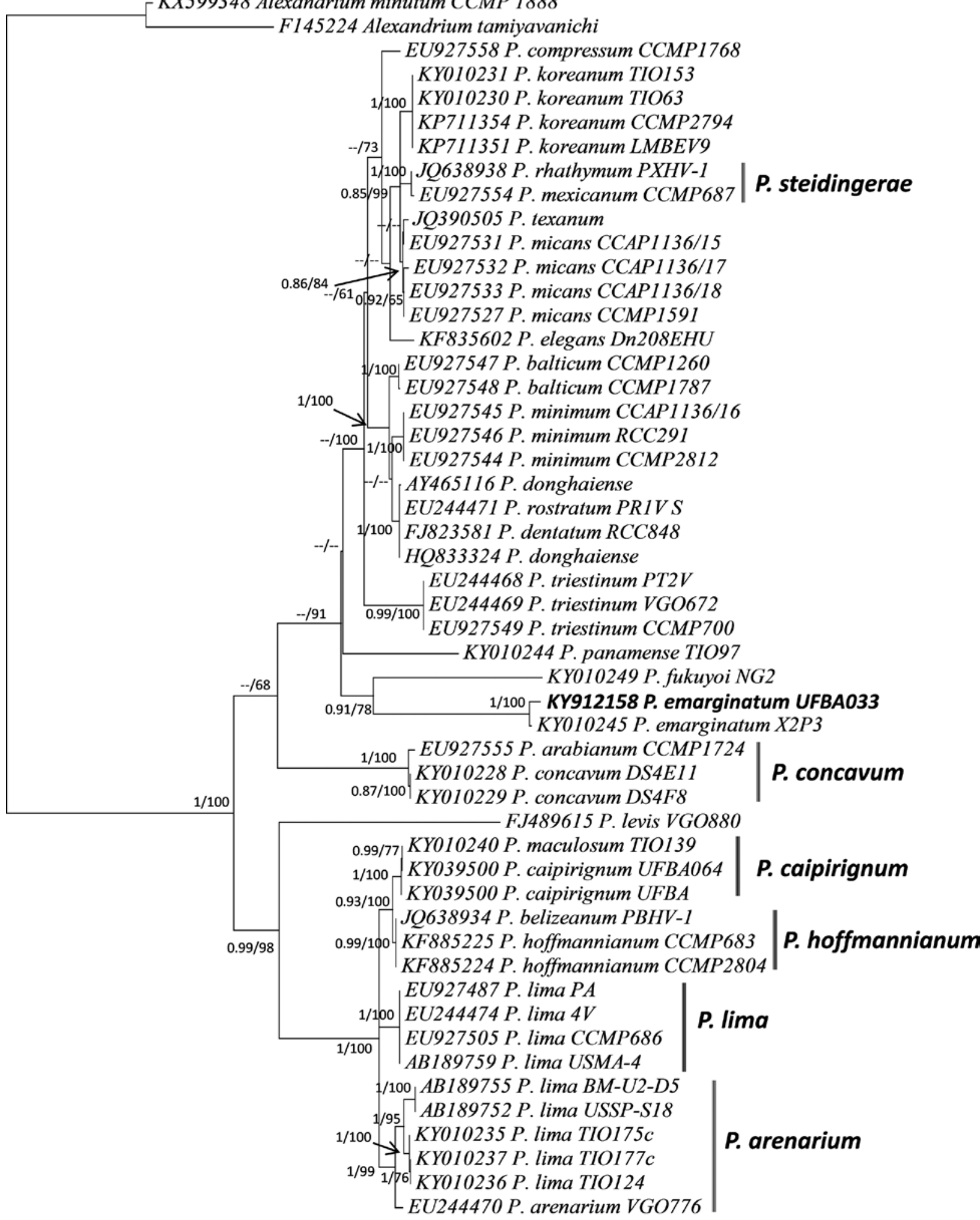

Figure 7: ITS phylogeny (ITS-1/5.8S/ITS-2) showing the relationship between Prorocentrum emarginatum strain (UFBA033) (in bold) and other Prorocentrum species.

Supports at internal nodes are bootstrap values obtained by the maximum likelihood method and Bayesian inference. Hyphens indicate bootstrap values $<50 \%$ and posterior probability $<0.5$. 
Coolia species based only on morphology can be problematic because of the small differences between some of them, their phenotypic plasticity and the possible occurrence of cryptic species (Mohammad-Noor et al. 2013, Leaw et al. 2016, Leung et al. 2017). In addition, clear divergences have been observed between Coolia clades and also within them (Leaw et al. 2016).

Regarding Coolia malayensis, some authors consider it to be synonymous with Coolia monotis (Hoppenrath et al. 2014), while others consider it to be a distinct species (Mohammad-Nor et al. 2013, Gómez et al. 2016, Leaw et al. 2016), supported by their different geographical distributions: tropical to warm-temperate for $C$. malayensis and temperate for $C$. monotis. Coolia malayensis was first described from Malaysian waters, of the South China Sea by Leaw et al. (2016). They recognized significant differences between the new species and C. monotis; however, they indicated that the two species were distinguished by the postcingular plate $3^{\prime \prime \prime}$ being the largest plate of the hypotheca in $C$. malayensis, whereas in $C$. monotis plate $3^{\prime \prime \prime}$ had almost the same size as plate 4"'. Likewise, Leaw et al. (2016) pointed out that the shape of plate 3' differed between the species, being quadrangular in C. malayensis and pentagonal in C. monotis.

The Bahia strain UFBA044 was identified as Coolia malayensis (Leaw et al. 2016) and differed from the other Brazilian isolates described by Gómez et al. (2016) by the dimensions of plate $3^{\prime \prime \prime}$. In the Bahia strain, plate $3^{\prime \prime \prime}$ was the largest of the hypothecal plates, while in Gómez et al. (2016) plate $3^{\prime \prime \prime}$ showed almost the same size as plate 4"'. The findings of Gómez et al. (2016) matched with some specimens described from Korean isolates by Jeong et al. (2012) who reported some specimens of $C$. malayensis with similar sizes for plates $3^{\prime \prime \prime}$ and 4"', in addition to specimens with plate $3^{\prime \prime \prime}$ larger than plate $4^{\prime \prime \prime}$ as observed in our study. The molecular results supported the use of the size of the third postcingular plate ( $\left.3^{\prime \prime \prime}\right)$, that is the largest plate in the hypotheca, as a diacritical feature in the circumscription of the Bahia strain of $C$. malayensis. The validity of this character has been claimed because it is present in a great number of genetically distinct $C$. malayensis isolates from tropical to warm subtropical regions in both Atlantic and Pacific Oceans (Jeong et al. 2012, Wakeman et al. 2015, Leaw et al. 2016).

Strain UFBA055 showed morphological features in agreement with the original description of Coolia tropicalis (Mohammad-Noor et al. 2013). The strain identified as C. tropicalis differed from the Coolia malayensis strain, mainly in the dimension of the precingular plate 6" (three times wider than long) and in the shapes of the apical plate 4', which were hexagonal and pentagonal, respectively.
Moreover, in C. tropicalis, plate $4^{\prime}$ widening towards the ventral side of the cell was the largest plate of the epitheca. This feature is shared with Coolia canariensis Fraga and Coolia areolata Ten-Hage, Turquet, Quod et Couté. However, C. canariensis and C. areolata exhibit theca areolates whereas $C$. tropicalis has a smooth theca (Jeong et al. 2012, Leaw et al. 2016).

The results of our LSU rDNA phylogeny corroborated previous studies that proposed Coolia malayensis, Coolia monotis, Coolia santacroce Karafas, Tomas et York, Coolia palmirensis Karafas, Tomas et York, Coolia tropicalis and Coolia canariensis to be monophyletic lineages representing distinct species (Jeong et al. 2012, Mohammad-Nor et al. 2013, Leaw et al. 2016). The results of this LSU rDNA phylogeny also supported the hypothesis that $C$. malayensis has a circumtropical distribution and suggests that so far there is no overlap yet with the geographical area occupied by C. monotis (Gómez et al. 2016).

The clade of Coolia malayensis showed intraspecific variability with the new Brazilian sequence of $C$. malayensis (UFBA044), diverging earlier than the other strains. However, the genetic distances within this clade were much lower than net genetic distances between clades. No significant differences were observed between the isolates from the South and the North Atlantic Ocean, Oceania and Asian areas, as indicated in previous studies (Gómez et al. 2016, Leaw et al. 2016).

The molecular phylogeny of the Brazilian strain of Coolia tropicalis also corroborated that the hexagonal shape of the apical plate $4^{\prime}$ widening towards the ventral side of the cell and the dimension of the postcingular plate 6" are good features separating $C$. tropicalis from Coolia malayensis. Additionally, the molecular phylogeny corroborated the validity of the thecal surface ornamentation for separating $C$. tropicalis from Coolia canariensis (there are no available genetic sequences for Coolia areolata). These results are in agreement with previous studies (Jeong et al. 2012). The phylogenetic analysis indicated that $C$. tropicalis and $C$. canariensis diverged before separating from Coolia monotis and $C$. canariensis, and that C. tropicalis originated in a tropical area, sharing a similar geographical distribution with $C$. malayensis, as pointed by Leaw et al. (2016). This analysis showed no distinguishable geographical traits, such as in the case of $C$. malayensis. However, the number of sequences for this species is still insufficient to confirm this proposition.

The Bahia strain fitted well with the morphology of Prorocentrum emarginatum according to the original description of Fukuyo (1981); the platelet formula was close to that described by Hoppenrath et al. (2014). However, in this material, eight platelets have been observed in the 
periflagellar area $(1,2,3,4,5,6 \mathrm{a}, 6 \mathrm{~b}, 8)$ and apparently, platelet 7 was hidden by the wing-shaped spine bordering platelet 1. Prorocentrum emarginatum is very close to Prorocentrum fukuyoi. Both species have a collar or flange along the right boundary of the apical region and also have three large plates in a row at the anterior end of the apical region (Murray et al. 2007). However, the strain in this study showed cells larger than P. fukuyoi $(18-30 \mu \mathrm{m})$. Also, the pore pattern of this material was more regularly radiating from the center, being closer to $P$. emarginatum than to P. fukuyoi.

The molecular phylogenetic results based on ITS rDNA regions showed a moderate support for the branching pattern between Prorocentrum emarginatum and Prorocentrum fukuyoi. Indeed, the morphological differentiation between the two species is difficult, and the cell width and the distribution of the pore pattern may be valuable diacritical characters in separating these species. More accurate studies of morphology are needed to validate these characters as well as others indicated in other studies (Murray et al. 2007, Hoppenrath et al. 2014, Luo et al. 2017). Moreover, the possible occurrence of morphologically cryptic or semicryptic species has been shown in P. emarginatum, P. fukuyoi and related species (LazaMartinez et al. 2011).

In the ITS phylogeny, the Bahia strain of Prorocentrum emarginatum matched a sequence of $P$. emarginatum from China (Luo et al. 2017). However, in Luo et al. (2017), P. emarginatum segregated together with Prorocentrum fukuyoi (KY010249), before other symmetrical and asymmetrical Prorocentrum sequences, whereas in the present work P. fukuyoi (KY010249), P. emarginatum (KY010245) and the Brazilian strain (KY912158), diverged after the $P$. concavum clade but within the group including other asymmetrical species. Although more accurate studies on the group are needed, including a larger number of sequences analyzed using multiple markers, the high support value between the Brazilian material and the Chinese isolate led us to consider both sequences as $P$. emarginatum. In general, species are often phenotypically distinct as they evolve separately and/or may diverge from one another depending on their adaptation to particular niches. Although these phenotypic differences may serve as relevant evidence for species delimitation, it is necessary to consider that morphological and ecological divergence, as well as reproductive isolation, have not yet developed. In these cases, delimitation of species based on phenotypic data is problematic, particularly in newly divergent species and morphologically simple taxonomic groups, such as many algae (Leliaert and De Clerck 2017).
Okadaic acid (OA) or its derivates were not detected in Prorocentrum emarginatum (UFBA033) but the results from the hemolytic assay revealed that the species produces some hemolytic compound which causes erythrocyte lysis. Aligizaki et al. (2009) reported no toxicity of coastal Greek strains of $P$. emarginatum using protein phosphatase type 2A inhibition assay (PP2AIA) and Artemia salina bioassay. There are few toxicity analyses related to this species, so it is necessary to carry out detailed studies to identify new compounds produced by $P$. emarginatum.

Biotoxins and bioactive compounds produced by Coolia species have not been well characterized. However, the toxicity has been demonstrated in some species by biological assays on mice, fish and invertebrates, or hemolytic assays (Leung et al. 2017). Herein, the hemolytic activity detected in Coolia tropicalis (UFBA055) and Coolia malayensis (UFBA044) strains highlights the potential risks of this group of harmful dinoflagellates in Brazilian waters. More studies are needed to identify toxic compounds in the two Coolia strains, to elucidate the hemolytic activity detected in Prorocentrum emarginatum (UFBA033) strains, and to identify possibly new compounds that may explain this activity.

Acknowledgments: This study was funded by projects FAPESB - RED0006/2012 and CNPq (Productivity Scholarship in Research \# 07368/2015-7), which were granted to J.M.C. Nunes; another CNPq grant (\# 471303/2013-5) was granted to M. Menezes; the scholarships from CAPES (PhD scholarship \# 9947-14-14-0/2014) and FAPESB (PhD scholarship Bol \# 10685/2013) were granted to M.C.Q. Mendes. The authors would like to address their appreciation to MARENBA/IB/UFBA for the strain cultures; to SME (Serviço de Microscopia Eletrônica from Instituto de Pesquisa Gonçalo Moniz, Fundação Oswaldo Cruz-FIOCRUZ) for the SEM studies; and to Mrs. Isabel Manzano of the $\mathrm{Cz}$ Veterinaria (Porriño, Pontevedra, Spain) for kindly providing us with the sheep blood. This study has also been supported by CCVIEO project and it is a contribution of Unidad Asociada IEO-CSIC Microalgas Nocivas.

\section{References}

Aligizaki, K., G. Nikolaidis, P. Katiko, D. Athanasios, A.D. Baxevanis and T.J. Abatzopoulos. 2009. Potentially toxic epiphytic Prorocentrum (Dinophyceae) species in Greek coastal waters. Harmful Algae 8: 299-311.

Berdalet, E., P.A. Tester, M. Chinain, S. Fraga, R. Lémée, W. Litaker, A. Penna, G. Usup, M. Vila and A. Zingone. 2017. Harmful 
algal blooms in benthic systems: recent progress and future research. Oceanography 30: 36-45.

Besada, E.G., L.A. Loeblich and A.R. Loeblich III. 1982. Observations on tropical, benthic dinoflagellates form ciguatera-endemic areas: Coolia, Gambierdiscus, and Ostreopsis. Bull. Mar. Sci. 32: 723-735.

Boopathi, T., D.G. Faria, J.Y. Cheon, S.H. Youn and J.S. Ki. 2015. Implications of high molecular divergence of nuclear rRNA and phylogenetic structure for the dinoflagellate Prorocentrum (Dinophyceae, Prorocentrales). J. Eukaryot. Microbiol. 62: 519-531.

Fritz, L. and R.E. Triemer. 1985. A rapid simple technique utilizing calcofluor white M2R for the visualization of dinoflagellate thecal plates. J. Phycol. 21: 662-664.

Fukuyo, Y. 1981. Taxonomical study on benthic dinoflagellates collected in coral reef. Bull. Japan. Soc. Sci. Fish. 47: 967-978.

Glibert, P.M., J.M. Burkholder and T.M. Kana. 2012. Recent insights about relationships between nutrient availability, forms, and stoichiometry, and the distribution, ecophysiology, and food web effects of pelagic and benthic Prorocentrum species. Harmful Algae 14: 231-259.

Gómez, F. 2005. A list of free-living dinoflagellate species in the world's oceans. Acta Bot. Croat. 64: 129-212.

Gómez, F., D. Qiu, E. Otero-Morales, R.M. Lopes and S. Lin. 2016. Circumtropical distribution of the epiphytic dinoflagellate Coolia malayensis (Dinophyceae): morphology and molecular phylogeny from Puerto Rico and Brazil. Phycol. Res. 64: 194-199.

Guillard, R.R.J. and S.L. Morton. 2004. Culture methods. In: (G.M. Hallegraeff, D.M. Anderson and A.D. Cembella, eds.) Manual on harmful marine microalgae. IOC Manual and Guides no. 33. UNESCO, Paris. pp. 77-97.

Hall, T.A. 1999. BioEdit: a user-friendly biological sequence alignment editor and analysis program for Windows 95/98/NT. Nucleic Acids Symp. Ser. 41: 95-98.

Hallegraeff, G.M. 2010. Ocean climate change, phytoplankton community responses, and harmful algal blooms: a formidable predictive challenge. J. Phycol. 46: 220-235.

Herrera-Sepúlveda, A., L.K. Medlin, G. Murugan, A.P. Sierra-Beltrán, A.A. Cruz-Villacorta and N.Y. Hernández-Saavedra. 2015. Are Prorocentrum hoffmannianum and Prorocentrum belizeanum (Dinophyceae, Prorocentrales), the same species? An integration of morphological and molecular data. J. Phycol 51: 173-188.

Holmes, M.J., R.J. Lewis, A. Jones and A.W. Wong Hoy. 1995. Cooliatoxin, the first toxin from Coolia monotis (Dinophyceae). Nat. Toxins 3: 355-362.

Hoppenrath, M., S.A. Murray, N. Chomérat and T. Horiguchi, eds. 2014. Marine benthic dinoflagellates - unveiling their worldwide biodiversity. Kleine Senckenberg-Reihe no. 54. Schweizerbart, Stuttgart. pp. 276.

Huelsenbeck, J.P. and F. Ronquist. 2001. MRBAYES: Bayesian inference of phylogenetic trees. Bioinformatics 17: 754-755.

Jeong, H.J., W. Yih, N.S. Kang, S.Y. Lee, E.Y. Yoon, Y.D. Yoo, H.S. Kim and J.H. Kim. 2012. First report of the epiphytic benthic dinoflagellates Coolia canariensis and Coolia malayensis in the waters off Jeju Island, Korea: morphology and rDNA sequences. J. Eukaryot. Microbiol. 59: 114-133.
Kimura, M. 1980. A simple method for estimating evolutionary rates of base substitutions through comparative studies of nucleotide sequences. J. Mol. Evol. 16: 111-120.

Kumar, S., G. Stecher and K. Tamura. 2016. MEGA7: molecular evolutionary genetics analysis version 7.0 for bigger datasets. Mol. Biol. Evol. 33: 1870-1874.

Laza-Martinez, A., E. Orive and I. Miguel. 2011. Morphological and genetic characterization of benthic dinoflagellates of the genera Coolia, Ostreopsis and Prorocentrum from the southeastern Bay of Biscay. Eur. J. Phycol. 46: 45-65.

Leaw, C.P., T.H. Tan, H.C. Lim, S.T. Teng, H.L. Yong, K.F. Smith, L. Rhodes, M. Wolf, W.C. Holland, M.W. Vandersea, R.W. Litaker, P.A. Tester, H. Gu, G. Usup and P.T. Lim. 2016. New scenario for speciation in the benthic dinoflagellate genus Coolia (Dinophyceae). Harmful Algae 55: 137-149.

Leliaert, F. and O. De Clerk. 2017. Refining species boundaries in algae. J. Phycol. 53: 12-16.

Lenaers, G., L. Maroteaux, B. Michot and M. Herzog. 1989. Dinoflagellates in evolution. A molecular phylogenetic analysis of large subunit ribosomal RNA. J. Mol. Evol. 29: 40-51.

Leung, P.T.Y., M. Yan, S.K.F. Yiu, V.T.T. Lam, J.C.H. Ip, M.W.Y. Au, C.-Y. Chen, T.-C. Wai and P.K.S. Lam. 2017. Molecular phylogeny and toxicity of harmful benthic dinoflagellates Coolia (Ostreopsidaceae, Dinophyceae) in a sub-tropical marine ecosystem: the first record from Hong Kong. Mar. Poll. Bull. 124: 878-889.

Luo, Z., H. Zhang, B. Krock, S. Lu, W. Yang and H. Gu. 2017. Morphology, molecular phylogeny and okadaic acid production of epibenthic Prorocentrum (Dinophyceae) species from the northern South China Sea. Algal Res. 22: 14-30.

Mendes, M.C.Q., J.M.C. Nunes, M. Menezes, S. Fraga, F. Rodríguez, J.A. Vázquez, J. Blanco, J.M. Franco and P. Riobó. 2017. Toxin production, growth kinetics and molecular characterization of Ostreopsis cf. ovata isolated from Todos os Santos Bay, tropical southwestern Atlantic. Toxicon 138: 18-30.

Migliaccio, O., I. Castellano, D. Di Cioccio, G. Tedeschi, A. Negri, P. Cirino, G. Romano, A. Zingone and A. Palumbo. 2016. Subtle reproductive impairment through nitric oxide-mediated mechanisms in sea urchins from an area affected by harmful algal blooms. Sci. Rep. 6: 26086.

Mohammad-Noor, N., Ø. Moestrup, N. Lundholm, S. Fraga, A. Adam, M.J. Holmes and E. Saleh. 2013. Autecology and phylogeny of Coolia tropicalis and Coolia malayensis (Dinophyceae), with emphasis on taxonomy of $C$. tropicalis based on light microscopy, scanning electron microscopy and LSU rDNA. J. Phycol. 49: 536-545.

Murray, S., Y. Nagahama and Y. Fukuyo. 2007. Phylogenetic study of benthic, spine-bearing prorocentroids, including Prorocentrum fukuyoi sp. nov. Phycol. Res. 55: 91-102.

Nascimento, S.M., P.O. Monteiro, C.E.E.L. Ferreira and G. Rodriguez. 2008. Ostreopsis ovata blooms on Rio de Janeiro coast. Harmful Algae News 37: 1-4.

Nascimento, S.M., F. Salgueiro, M. Menezes, F.A. Oliveira, V.C.P. Magalhães, J.C. De Paula and S. Morris. 2016. Prorocentrum lima from the South Atlantic: Morphological, molecular and toxicological characterization. Harmful Algae 57: 39-48.

Nascimento, S.M., M.C.Q. Mendes, M. Menezes, F. Rodríguez, C. Alves-de-Souza, S. Branco, P. Riobó, J. Franco, J.M.C. Nunes, M. Huk, S. Morris and S. Fraga. 2017. Morphology and phylogeny of Prorocentrum caipirignum sp. nov. (Dinophyceae), a new tropical toxic benthic dinoflagellate. Harmful Algae 70: 73-89. 
Nei, M. 1987. Molecular evolutionary genetics. Columbia University Press, New York. pp. 572.

Riobó, P., B. Paz, J.M. Franco, J.A. Vazquez and M.A. Murado. 2008. Proposal for a simple and sensitive haemolytic assay for palytoxin: Toxicological dynamics, kinetics, ouabain inhibition and thermal stability. Harmful Algae 7: 415-429.

Sato, S., T. Nishimura, K. Uehara, H. Sakanari, W. Tawong, N. Hariganeya, K. Smith, L. Rhodes, T. Yasumoto, Y. Taira, S. Suda, H. Yamaguchi and M. Adachi. 2011. Phylogeography of Ostreop sis along west Pacific coast, with special reference to a novel clade from Japan. PLoS One 6: e27983.

Tamura, K. and M. Nei. 1993. Estimation of the number of nucleotide substitutions in the control region of mitochondrial DNA in humans and chimpanzees. Mol. Biol. Evol. 10: 512-526.

Torgersen, T., C.O. Miles, T. Rundberget and A.L. Wilkins. 2008. New esters of okadaic acid in seawater and blue mussels (Mytilus edulis). J. Agric. Food Chem. 56: 9628-9635.

Truby, E.W. 1997. Preparation of single-celled marine dinoflagellates for electron microscopy. Microsc. Res. Tech. 36: 337-340.

Villac, M.C. and D.R. Tenenbaum. 2010. The phytoplankton of Guanabara Bay, Brazil. I. Historical account of its biodiversity. Biota Neotrop. 10: 271-293.

Wakeman, K.C., A. Yamaguchi, M.C. Roy and H. Jenke-Kodama. 2015. Morphology, phylogeny and novel chemical compounds from Coolia malayensis (Dinophyceae) from Okinawa, Japan. Harmful Algae 44: 8-19.

\section{Bionotes}

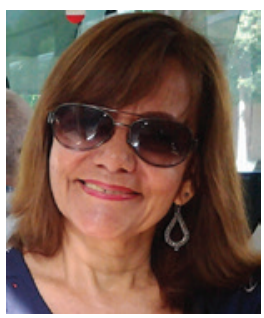

\section{Maria Cristina de Queiroz Mendes}

Universidade Federal da Bahia, Instituto de Biologia, Programa de Pós-Graduação em Ecologia e Biomonitoramento (ECOBIO), Av. Barão Jeremoabo, Campus Ondina, Salvador, BA 40170-115, Brasil, cristinaqmendes@gmail.com

Maria Cristina de Queiroz Mendes obtained her doctorate in ecology at the Universidade Federal da Bahia, Brazil. Her thesis focused on the structure of the marine dinoflagellate community, with emphasis on potentially harmful species. She has collaborated in some projects about microalgae involving taxonomy, ecology and biodiversity.

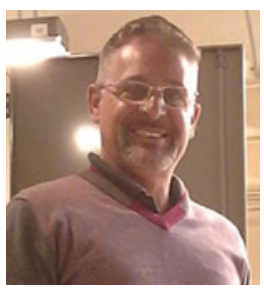

José Marcos de Castro Nunes

Universidade Federal da Bahia, Instituto de Biologia, Laboratório de Algas Marinhas (LAMAR), Av. Barão Jeremoabo, Campus Ondina, Salvador, BA 40170-115, Brasil the Laboratorio de Algas Marinhas (LAMAR). Associate Researcher at Harvard University Herbaria, where he performs postdoctoral studies on marine macroalgal genomics. He has dedicated himself to the study of ecology of marine microalgae.

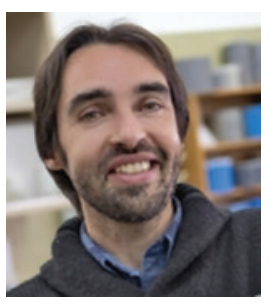

Francisco Rodríguez

Instituto Español de Oceanografía (IEO), Centro Oceanográfico de Vigo, Subida a Radio Faro, 50, Vigo 36390, Spain

Francisco Rodríguez is senior researcher at Spanish Institute of Oceanography (IEO) since 2005. Before, he obtained his doctorate in 2002 in the University of Vigo and stayed 2 years as postdoctoral researcher in the Roscoff Marine Station. His current interests are marine harmful algae, including their taxonomical study using molecular tools and their ecophysiology (photosynthetic dynamics and pigments). As indicators of scientific production his $h$-index is 22 and cites/year 182 (2013-2017).

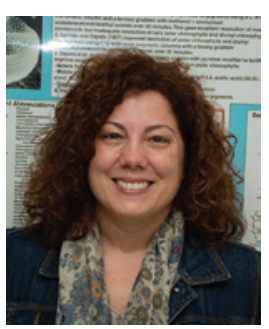

\section{Pilar Riobó} Instituto de Investigaciones Marinas (IIM-CSIC), C/Eduardo Cabello, 6 , Vigo 36208, Spain

Pilar Riobó studied Biology at the University of Vigo. In 2001, she began to work in the field of marine toxic dinoflagellates at the Spanish Institute of Oceanography in Vigo. In 2008, she defended her thesis on this topic. Since 2005 , she has worked as Senior Research Technician at the Marine Research Institute (CSIC-Vigo) with a focus on the chemical and biological analyses of marine biotoxins present in microalgae and other organisms like mollusks or fishes.

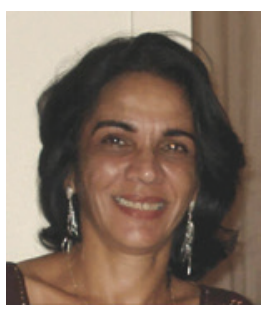

\section{Mariângela Menezes}

Universidade Federal do Rio de Janeiro, Museu Nacional, Departamento de Botânica, Laboratório de Ficologia, Quinta da Boa Vista, São Cristovão, Rio de Janeiro, RJ 20940-040, Brasil

Mariângela Menezes is a Full Professor at the Federal University of Rio de Janeiro (UFRI), National Museum, Department of Botany. She works on microalgal taxonomy and biodiversity, and her main research interests are ultrastructure, molecular phylogeny and evolution of toxic phytoflagellates.
José Marcos de Castro Nunes, PhD in Sciences from the Universidade de São Paulo, Brazil (2005). Has 35 years of experience in marine algal taxonomy, systematics and ecology. Professor at the Universidade Federal da Bahia, Brazil since 1990. Coordinator of 